\title{
Successful One and One-half Ventricular Circulation with Bioprosthetic Tricuspid Valve Replacement and Total Chordal Preservation in a Patient with Ebstein's Anomaly: A Video Presentation
}

\author{
Ujjwal K. Chowdhury ${ }^{1, \odot ~ S u k h j e e t ~ S i n g h ~}{ }^{1} \quad$ Niwin George ${ }^{1} \quad$ Lakshmi Kumari Sankhyan $^{1}$ \\ Sandeep Sharan ${ }^{1}$ Poonam Malhotra Kapoor ${ }^{1} \quad$ Abhinav Singh Chauhan $^{1}$ Parag Gharde ${ }^{1}$ \\ Sushama Gayatri B ${ }^{1}$ Sanjoy Sengupta ${ }^{1}$
}

${ }^{1}$ Cardio-Thoracic Sciences Centre, All India Institute of Medical

Address for correspondence Dr. Ujjwal Kumar Chowdhury, Sciences, New Delhi, India M.Ch, Diplomate NB, Professor, Department of Cardiothoracic and Vascular Surgery, All India Institute of Medical Sciences, New Delhi-110029, India (e-mail: ujjwalchow@rediffmail.com, ujjwalchowdhury@gmail.com).

\author{
Abstract \\ Keywords \\ - bioprosthetic tricuspid \\ valve replacement \\ - Ebstein's anomaly \\ - one and one-half \\ ventricular circulation \\ - total chordal \\ preservation
}

Ebstein's anomaly is a rare congenital malformation of the right ventricle and tricuspid valve which is characterized by several features that can exhibit an infinite spectrum of malformation.

The abnormalities include: i) adherence of the tricuspid leaflets to the underlying myocardium (failure of delamination); ii) anterior and apical rotational displacement of the functional tricuspid annulus (septal > posterior > anterior leaflet); iii) dilatation of the right atrioventricular junction (the true tricuspid annulus) with variable degrees of hypertrophy and thinning of the wall; iv) dilatation of the "atrialized" portion of the right ventricle; and v) redundancy, fenestration, and tethering of the anterior leaflet.

\section{Introduction}

Ebstein's anomaly is a rare congenital malformation of the right ventricle and tricuspid valve which is characterized by several features that can exhibit an infinite spectrum of malformation. ${ }^{1-4}$

The abnormalities include: i) adherence of the tricuspid leaflets to the underlying myocardium (failure of delamination); ii) anterior and apical rotational displacement of the functional tricuspid annulus (septal $>$ posterior $>$ anterior leaflet); iii) dilatation of the right atrioventricular junction (the true tricuspid annulus) with variable degrees of hypertrophy and thinning of the wall; iv) dilatation of the "atrialized" portion of the right ventricle; and v) redundancy, fenestration, and tethering of the anterior leaflet.

published online August 16, 2021
DOI https://doi.org/ $10.1055 / \mathrm{s}-0041-1723626$ ISSN 2457-0206.
This results in a downward displacement of the hinge point of the posterior and septal leaflets in a spiral fashion below the true annulus. With increasing degrees of anatomical severity of malformation, the fibrous transformation of leaflets from their muscular precursors remains incomplete, with the septal leaflet being the most severely involved and the anterior leaflet being the least severely involved. ${ }^{1-4}$

In the natural history, a significant increase in mortality is observed in adulthood due to the development of congestive heart failure or arrhythmias. ${ }^{5-7}$ The sudden death caused by arrhythmias not related to Wolff-Parkinson-White (WPW) syndrome occurs in $60 \%$ of patients who die due to cardiac causes and correlates more with cardiomegaly. ${ }^{8,9}$

Indications for operation have included symptomatic patients in New York Heart Association functional class III, IV, (c) 2021. Official Publication of The Simulation Society (TSS), accredited by International Society of Cardiovascular Ultrasound (ISCU).

This is an open access article published by Thieme under the terms of the Creative Commons Attribution-NonDerivative-NonCommercial-License, permitting copying and reproduction so long as the original work is given appropriate credit. Contents may not be used for commercial purposes, or adapted, remixed, transformed or built upon. (https://creativecommons.org/licenses/by-nc-nd/4.0/) Thieme Medical and Scientific Publishers Pvt. Ltd., A-12, 2nd Floor, Sector 2, Noida-201301 UP, India 
progressive deterioration of exercise capacity, congestive cardiac failure, cyanosis (systemic arterial oxygen saturation < $90 \%$ ), paradoxical embolism in functional classes I and II with progressive cardiomegaly on chest X-ray (cardiothoracic ratio > 0.6), progressive right ventricular enlargement on echocardiography and onset or progression of uncontrollable right ventricular arrhythmias and accessory atrioventricular bundle. ${ }^{1,5-10}$

Medical therapy has been recommended for asymptomatic patients with low normal exercise tolerance, no right-to-left shunting, and only mild cardiomegaly. Relative contraindications to tricuspid valve repair include older age ( $>50$ years), moderate pulmonary hypertension, poor left ventricular ejection fraction $(\leq 30 \%)$, complete failure of delamination of the septal and inferior leaflets with poor delamination of the anterior leaflet (i.e., < 50\% delamination of the anterior leaflet), cardiothoracic ratio $>0.8$ with massive right ventricular enlargement, and severe dilatation of the right atrioventricular junction (true tricuspid annulus). ${ }^{1,5-10}$

Numerous techniques of repair have been described since the first report of Hunter and Lillehei. ${ }^{11}$ The Danielson method originally described in 1992 is the oldest tricuspid valvuloplasty procedure. ${ }^{10}$ No two hearts with Ebstein's anomaly have exactly the same anatomy. Anatomical and echocardiographic study as well as surgical experience suggest that the right ventricle and its shape, compliance and contractility may be as important as tricuspid valve dysfunction in the pathophysiology of the disease.

In 1988, Carpentier and associates classified the various anatomical variations of the disease and developed an innovative technique of reconstruction. It consists of reconstruction of the right ventricle form and repositioning of the tricuspid valve at the normal level with the routine use of a prosthetic ring. ${ }^{11}$

Quagebeur and associates used a similar surgery, but without the prosthetic ring, in a younger population. ${ }^{12}$ In 1989, deSilva and associates developed a surgical technique of conical reconstruction of the tricuspid valve. ${ }^{13}$ It consists of total or almost total detachment of the large anterior tricuspid leaflet from the ventricular wall and valvular ring, transforming into a cone, whose vertex remained fixed in the right ventricular tip and the base was sutured to the tricuspid valve ring. The suture of the base of this cone is performed at the normal level of the tricuspid ring including its septal portion, where the suture line needs to be superficial, avoiding atrioventricular block without using any prosthetic ring. ${ }^{12-15}$

When the tricuspid valve cannot be reconstructed, a prosthetic valve (preferably bioprosthetic than mechanical) with total chordal preservation is the procedure of choice. The suture line for the prosthetic valve is delineated cephalad to the atrioventricular node, bundle of His and membranous septum. The atrioventricular node is typically marked by a small vein crossing the tricuspid annulus lateral to the membranous septum. In order to avoid injury to the right coronary artery, the suture line is deviated cephalad to the tricuspid annulus posterolaterally when the tissues are very thin. The coronary sinus can be left to drain into the right atrium if there is sufficient room between it and the atrioventricular node; if this is short, the coronary sinus may he left to drain into the right ventricle. ${ }^{1,16}$

The bioprostheses should be oriented, so that the prosthetic struts straddle the area of the membranous septum and conduction tissue. The tricuspid valve replacement is preferably performed on a beating perfused heart in order to detect any conduction abnormalities. ${ }^{1,16}$ In patients with dysfunctional right ventricle and those patients with Ebstein's anomaly undergoing aggressive tricuspid valve annuloplasty may be suitable candidates for an elective one and one-half ventricular circulation. . $^{215,17-25}$

In the Mayo Clinic experience on 323 patients with Ebstein's anomaly undergoing surgical correction, tricuspid valvular reconstruction was possible in $42.7 \%$ cases; a prosthetic valve, usually bioprosthesis, was implanted in $54.8 \%$ and a modified Fontan procedure was performed in $2.5 \%$ of cases. ${ }^{1,16}$ The incidence of hospital and late mortalities were $6.5 \%$ and $7.6 \%$, respectively. Between 1.5 and 17.7 years (mean 9.4), $16.7 \%(n=23)$ of 138 patients required redo valve repair. ${ }^{1,16}$

In 1998, Kiziltan and associates reported the late results of tricuspid valve replacement in 158 patients with Ebstein's anomaly undergoing bioprosthesis implantation. ${ }^{26}$ The freedom from bioprosthetic re-replacement was $97.5 \% \pm 1.9 \%$ after 5 years and $80.6 \% \pm 7.6 \%$ after 10 and 15 years. The freedom from reoperation after tricuspid valve repair and replacement are similar (81.9\% vs. 83.1\%). ${ }^{26}$ Published literature documents greater durability of bioprostheses in tricuspid valve replacement in both pediatric and adult populations as compared with bioprosthetic implant in other cardiac positions. Accommodation of a large size bioprosthesis and low right ventricular systolic pressure would tend to reduce turbulence and stress on the bioprosthesis, resulting in longer freedom from degeneration..$^{27,28}$

We report herein a 7-year-old male child diagnosed to have congenital heart disease with type D Ebstein's malformation in New York Heart Association class III who underwent tricuspid valve replacement using a $29 \mathrm{~mm}$ St. Jude Epic bioprosthesis, patch closure of the atrial septal defect with a concomitant pulsatile bidirectional Glenn. Postoperative recovery was uneventful.

\section{Surgical Techniques}

Following median sternotomy, the thymus was subtotally excised, taking care not to injure the brachiocephalic vein. The pericardium was opened using scissors and not cautery to avoid inadvertent cautery-induced ventricular fibrillation.

Note the grossly dilated right atrium and the atrialized right ventricle. The operation is performed with moderately hypothermic cardiopulmonary bypass at $28^{\circ} \mathrm{C}$, angled venous cannula into the superior vena cava, and a straight cannula into inferior vena cava with distal aortic cannulation. Antegrade cold hyperkalemic St. Thomas based (1:4) blood cardioplegia and topical cooling with iced saline is used for myocardial protection.

The right atrium was incised from the atrial appendage to the inferior vena cava $1 \mathrm{~cm}$ away from the right atrioventricular groove. 
Note two papillary muscles arising from the free wall of the right ventricle with short chordal attachments to the leading edge of the anterior leaflet. The anterior leaflet is large and of sail-like configuration.

The septal leaflet is diminutive. The posterior leaflet is not well-formed, adherent to the underlying endocardium, and is displaced down from the annulus. A small patent foramen ovale is present.

The atrial septal defect was closed using a Dacron polyester patch (Bard Savage filamentous knitted polyester fabric, Bard Peripheral Vascular Inc., Tempe, AZ, USA).

Due to severity of tricuspid valve pathology, the tricuspid valve was deemed irreparable and elective tricuspid valve replacement was planned. The aortic cross-clamp was released, thus restoring myocardial perfusion.

A $29 \mathrm{~mm}$ St. Jude Epic bioprosthesis (St. Jude Medical; St. Paul, MN, USA) was implanted in the tricuspid position using interrupted 2-0 pledgeted tricron mattress sutures $(\mathrm{M} / \mathrm{s}$ Covidien Domingo, Dominican Republic, USA).

The coronary sinus was left to drain within the right atrium. The valve leaflets were checked for competence insufflating normal saline within the right ventricular cavity. The tricuspid chordal mechanism was totally preserved.

The right atrium was closed in two layers of 5-0 polypropylene sutures (Johnson and Johnson Ltd., Ethicon, LLC, San Lorenzo, USA). The patients were weaned off cardiopulmonary bypass with stable hemodynamics on dopamine $5 \mu \mathrm{g} / \mathrm{kg} / \mathrm{min}$, dobutamine $5 \mu \mathrm{g} / \mathrm{kg} / \mathrm{min}$, and nitroglycerine $0.1 \mu \mathrm{g} / \mathrm{kg} / \mathrm{min}$ (Video 1).

\section{Results}

Postoperative recovery was uneventful. Postoperative echocardiography demonstrated normal biventricular function with normally functioning prosthetic tricuspid valve and normal leaflet coaptation without tricuspid regurgitation.

At 3 months follow-up, the patient was asymptomatic in New York Heart Association functional class I without any antifailure medication.

\section{Conclusions}

We conclude that for severe, irreparable form of Ebstein's malformation, tricuspid valvular reconstruction may not be feasible. Tricuspid valve replacement with total chordal preservation and concomitant closure of atrial septal defect eliminates intracardiac right-to-left shunting with its attendant risks, reduces supraventricular arrhythmias, and improves exercise tolerance and functional class. For severe forms of Ebstein's anomaly, conversion to a one- and one-half ventricular circulation allows a hypoplastic/dysfunctional right ventricle to adequately handle the reduced preload. Total chordal preservation of the right ventricle preserves right ventricular function.

\section{Conflicts of Interests}

The author (s) declared no potential conflicts of interest with respect to the research, authorship, and/or publication of the article.

\section{Funding}

The authors received no financial support for the research, authorship, and/or publication of this article.

\section{Video 1}

Online content including video sequences viewable at: https://www.thieme-connect.com/products/ejournals/ html/10.1055/s-0041-1723626

\section{References}

1 Danielson GK. Surgical management of Ebstein's anomaly. Prog Pediatr Cardiol 1993;2(1):51-60

2 Anderson KR, Lie JT. The right ventricular myocardium in Ebstein's anomaly: a morphometric histopathologic study. Mayo Clin Proc 1979;54(3):181-184

3 Anderson KR, Zuberbuhler JR, Anderson RH, Becker AE, Lie JT. Morphologic spectrum of Ebstein's anomaly of the heart: a review. Mayo Clin Proc 1979;54(3):174-180

4 Dearani JA, Danielson GK. Congenital heart surgery nomenclature and database project: Ebstein's anomaly and tricuspid valve disease. Ann Thorac Surg 2000;69(4, Suppl):S106-S117

5 Celermajer DS, Bull C, Till JA, et al. Ebstein's anomaly: presentation and outcome from fetus to adult. J Am Coll Cardiol 1994;23(1):170-176

6 Giuliani ER, Fuster V, Brandenburg RO, Mair DD. Ebstein's anomaly: the clinical features and natural history of Ebstein's anomaly of the tricuspid valve. Mayo Clin Proc 1979;54(3):163-173

7 Hansen JF, Leth A, Dorph S, Wennevold A. The prognosis in Ebstein's disease of the heart. Long-term follow-up of 22 patients. Acta Med Scand 1977;201(4):331-335

8 Gentles TL, Calder AL, Clarkson PM, Neutze JM. Predictors of long-term survival with Ebstein's anomaly of the tricuspid valve. Am J Cardiol 1992;69(4):377-381

9 Watson H. Natural history of Ebstein's anomaly of tricuspid valve in childhood and adolescence. An international co-operative study of 505 cases. Br Heart J 1974;36(5):417-427

10 Danielson GK, Driscoll DJ, Mair DD, Warnes CA, Oliver WC Jr. Operative treatment of Ebstein's anomaly. J Thorac Cardiovasc Surg 1992;104(5):1195-1202

11 Hunter SW, Lillehei CW. Ebstein's malformation of the tricuspid valve; study of a case together with suggestion of a new form of surgical therapy. Dis Chest 1958;33(3):297-304

12 Carpentier A, Chauvaud S, Macé L, et al. A new reconstructive operation for Ebstein's anomaly of the tricuspid valve. J Thorac Cardiovasc Surg 1988;96(1):92-101

13 Quaegebeur JM, Sreeram N, Fraser AG, et al. Surgery for Ebstein's anomaly: the clinical and echocardiographic evaluation of a new technique. J Am Coll Cardiol 1991;17(3):722-728

14 da Silva JP, Baumgratz JF, Fonseca L, et al. Ebstein's anomaly. Results of the conical reconstruction of the tricuspid valve. Arq Bras Cardiol 2004;82:217-220

15 Dearani JA, Bacha E, da Silva J. Cone reconstruction of the tricuspid valve for Ebstein's anomaly: anatomic repair. Oper Tech Thorac Cardiovasc Surg 2008;13:109-125

16 Theodoro DA, Danielson GK, Kiziltan HT, et al. Surgical management of Ebstein's anomaly: 25 year experience. Circulation 1997;96(Suppl. I) :I-121

17 da Silva JP, Baumgratz JF, da Fonseca L, et al. The cone reconstruction of the tricuspid valve in Ebstein's anomaly. The operation: early and midterm results. J Thorac Cardiovasc Surg 2007;133(1):215-223 
18 Quinonez LG, Dearani JA, Puga FJ, et al. Results of the 1.5-ventricle repair for Ebstein anomaly and the failing right ventricle. J Thorac Cardiovasc Surg 2007;133(5):1303-1310

19 BrownML,DearaniJA,DanielsonGK,etal; MayoClinicCongenital Heart Center. The outcomes of operations for 539 patients with Ebstein anomaly. J Thorac Cardiovasc Surg 2008;135(5): 1120-1136, 1136.e1-1136.e7

20 Chauvaud S. Ebstein's malformation. surgical treatment and results. Thorac Cardiovasc Surg 2000;48(4):220-223

21 Marianeschi SM, McElhinney DB, Reddy VM, Silverman NH, Hanley FL. Alternative approach to the repair of Ebstein's malformation: intracardiac repair with ventricular unloading. Ann Thorac Surg 1998;66(5):1546-1550

22 Numata S, Uemura H, Yagihara T, Kagisaki K, Takahash MI, Ohuchi $\mathrm{H}$. Longterm functional results of the one and one half ventricular repair for the spectrum of patients with pulmonary atresia/stenosis with intact ventricular septum. Eur J Cardiothorac Surg 2003;24:516-520

23 Chowdhury UK, Kumari LS, Singh S, et al. One and one half ventricular repair with pulsatile bi-directional Glenn: concept, concerns and future directions. Journal of Neonatal Care and Pediatric Research 2019;1(1):001-012

24 Chowdhury UK, Airan B, Sharma R, et al. One and a half ventricle repair with pulsatile bidirectional Glenn: results and guidelines for patient selection. Ann Thorac Surg 2001; 71(6):1995-2002

25 Chowdhury UK, Airan B, Talwar S, et al. One and one-half ventricle repair: results and concerns. Ann Thorac Surg 2005; 80(6):2293-2300 [cited by 82 related articles]

26 Kiziltan HT, Theodoro DA, Warnes CA, O'Leary PW, Anderson BJ, Danielson GK. Late results of bioprosthetic tricuspid valve replacement in Ebstein's anomaly. Ann Thorac Surg 1998;66(5):1539-1545

27 Williams DB, Danielson GK, McGoon DC, Puga FJ, Mair DD, Edwards WD. Porcine heterograft valve replacement in children. J Thorac Cardiovasc Surg 1982;84(3):446-450

28 Geha AS, Laks H, Stansel HC Jr, et al. Late failure of porcine valve heterografts in children. J Thorac Cardiovasc Surg 1979;78(3):351-364 